\title{
Study on Free cash flow, over-investment and cash dividend
}

\author{
Yulian Zhang ${ }^{a,{ }^{*}}$, Xuemeng Guo ${ }^{b}$ \\ Beijing Jiaotong University, Beijing, China \\ a.17120676@bjtu.edu.cn, b. xmguo@bjtu.edu.cn \\ "Corresponding author
}

Keywords: Over-investment, Free cash flow, Cash dividends.

\begin{abstract}
Effective investment is an important driving factor for the growth of the company and the growth of future cash flow, and it is the root of an enterprise to increase its value. However, according to the relevant research data, the excessive investment and underinvestment of listed companies in China are common, and the phenomenon of inefficient investment is serious. Therefore, how to restrain the inefficient investment of the listed companies to improve their investment efficiency has become one of the problems to be solved in practice. Because of information asymmetry, the size of free cash flow affects the size of the investment, which makes the company have a tendency to overinvest or underinvestment. But the dividend agent model also shows that the distribution of cash dividends will help enterprises to mitigate agency conflicts in order to reduce moral hazard, to solve the adverse selection problem caused by information asymmetry, and ultimately curb the interaction between investment and free cash flow. In this paper, based on the principal-agent theory and accounting theory, the research methods such as theoretical research and empirical research are adopted. This paper studies the correlation of free cash flow, cash dividend and over-investment, taking listed companies in China as samples. And the results of this study show that:(1) free cash flow and over investment are positively correlated; (2) cash dividend has restrictive effect on over investment.
\end{abstract}

\section{Introduction}

In recent years, China's economy has maintained a sustained and rapid growth. As one of the three carriages driving economic growth, the growth rate has also been steadily increased. However, too fast investment growth will lead to "economic overheating" at macro level, such as energy shortage, inflation, production capacity and social resources waste. As the enterprise is the carrier of the social and economic operation, the macro social "economic overheating" can directly bring the micro enterprise "over-investment".

Over-investment means that managers invest the free cash flow in the enterprise into projects with negative net present value. From the definition of over-investment, it can be seen that the reason why the enterprise has over-investment .The source is that the enterprise has abundant or even excessive free cash flow. The free cash flow of the enterprise refers to the surplus cash flow after all the funds needed to meet the net present value of the enterprise after the discount of the related capital cost. Therefore, in order to restrict the excessive investment of enterprises, the free cash flow of enterprises should be restricted. However, one of the most direct and effective ways to restrict the free cash flow of enterprises is to distribute cash dividends. A higher cash dividend payout rate can return the free cash flow of a company to shareholders in cash dividend, reduce the free cash flow within the enterprise and to a certain extent, limit its investment opportunities of negative net present value, and thus restrict excessive investment.

In this context, the question of this paper is put forward: is there a general over-investment in listed companies? What is the relationship between free cash flow and over-investment? If the rate of cash dividend payment is increased, is it possible to effectively restrict the phenomenon of excessive investment? What is the specific internal logical relationship between the over investment, the free cash flow and the cash dividend between the three parties? 


\section{Literature Review}

Before the Richardson, although the academic thought that over-investment and free cash flow may be a positive correlation, but no scholars carried out empirical analysis, and Richardson through the expected investment model construction of growth opportunities, demonstrated the relationship between over-investment and free cash flow[1]. On this basis, Liu Changguo, Yang Huajun and Hu Yiming all use Richardson's method to construct the econometric model of free cash flow and over investment, and make further research on how to reduce over-investment from different angles[2,3].

The research for cash dividend and investment efficiency of Kalay[4] pointed out that there is a close relationship between cash dividend and investment behavior, the low level of dividend payment rate makes more profits retained in the business, to provide investment opportunities for poor profitability of the enterprise, resulting in inefficient investment. From the perspective of free cash flow, Jensen found that dividend payout can reduce the available free cash flow and avoid managers' speculative behavior, thus prompting managers to make better investment decisions[5,6]. Some domestic scholars, such as Jin Fan and Xiao Min, have found that the distribution of cash dividends will help to solve the problem of excessive investment caused by the surplus of internal cash flow $[7,8]$.

\section{Research Hypothesis}

Due to the separation of business right and ownership, asymmetric information and inconsistent interests between managers and shareholders cause serious agency problems. When there is plenty of free cash flow in the enterprise, the potential possibility of over-investment by managers is greatly improved. Moreover, managers' remuneration, including explicit and implicit remuneration, is positively related to firm size. Therefore, managers also have incentives to invest in cash flows to non-profit projects that can bring benefits to themselves, which leads to over-investment. It has been found that the more enterprises with free cash flow, the larger the agency problem, the more serious the situation of over-investment. It can be seen that the large amount of free cash flow in the enterprise has indeed brought the conditions and motivation to the over-investment of the business operators. Therefore,we suggest a hypothesis:

H1: There is a significant positive correlation between free cash flow and over-investment. That means,the more free cash flow is owned by the enterprise, the more serious over-investment phenomenon is.

Scholars such as Rozeff and Easterbrook combined dividend policy with the agency cost theory proposed by Jense and formed dividend agent theory[9]. Rozeff points out that dividend payment can play a role in restricting and supervising enterprises. As the rate of dividend payment increases, the agency costs will decrease. Lamont and Ghose have found that the level of over-investment in enterprises is determined by cash in the hands of managers. In China, Tang Xuesong found that the listed companies in our country have over-investment behavior, and the cash dividend can effectively restrict the excessive investment. Liu Yinguo pointed out that when making the dividend policy, the management of state-owned enterprises is not to maximize the value of enterprises, but to consider how to expand the scale of enterprises and the phenomenon of over investment[10].

$\mathrm{H} 2$ : The issuance of cash dividends can reduce the free cash flow of the listed company operators, and then restrain the problem of over-investment caused by free cash flow.

\section{Empirical Research}

This paper selects 3583 listed companies as initial samples from 2010 to 2013.And initial samples were screened in accordance with the following criteria: (1) eliminate the ST enterprise during this period;(2) remove samples from listed companies in the financial and insurance sectors. On this basis, all samples with missing data were excluded, and some extreme values were further removed, and 7634 samples were obtained as initial sample data. 


\subsection{Variable Selection}

Firstly, this paper uses Richardson's calculation method of non-efficiency investment model to measure over-investment, and sets up the following model (1) to estimate the new investment expenditure of the enterprise:

$I_{N E W_{i, t}}=\alpha+\beta_{1}$ Growth $_{i, t-1}+\beta_{2}$ Leverage $_{i, t-1}+\beta_{3}$ Cash $_{i, t-1}+\beta_{4}$ Age $_{i, t-1}+\beta_{5}$ Size $_{i, t-1}+\beta_{6}$ Returns $_{i, t-1}+\beta_{7} I_{N E W_{i, t}}$

The fitting value of the new investment expenditure by the regression estimate is the expected investment expenditure of the enterprise, and the positive value of the residual value obtained is the over-investment level of the enterprise, which is defined as Over_inv.

As mentioned above, Jensen's free cash flow is defined as the residual cash flow of an enterprise after investing in all of its positive net present value. In this line of thought, this article uses the net cash flow as a free cash flow, minus all the investment needed for a positive project.

Due to the company's growth, financial leverage and monetary fund, the age, size, yield and big shareholders will have an effect on free cash flow, so we will regard these varibles as control variables to join the models that have been set.

For the variables mentioned above, all variables and their measures are designed into a table, as shown in the table 1:

Table 1. Specific Description of Variables

\begin{tabular}{|c|c|c|c|}
\hline Type & Variable Name & $\begin{array}{l}\text { Symbol of } \\
\text { Variable }\end{array}$ & Definition \\
\hline \multirow{3}{*}{$\begin{array}{l}\text { The transition } \\
\text { variable }\end{array}$} & The total investment & IT & $\begin{array}{l}\text {-Net cash flow of investment } \\
\text { activities/Total asset }\end{array}$ \\
\hline & $\begin{array}{c}\text { Maintenance } \\
\text { investment }\end{array}$ & IM & $\begin{array}{c}\text { Depreciation and } \\
\text { amortization/Total asset }\end{array}$ \\
\hline & $\begin{array}{l}\text { New investment } \\
\text { spending }\end{array}$ & IN & $\begin{array}{c}\text { The total investment-Maintenance } \\
\text { investment }\end{array}$ \\
\hline Dependent Variable & over-investment & Over_inv & $\begin{array}{l}\text { Regression residual of model } 1 \text { is } \\
\text { greater than } 0 .\end{array}$ \\
\hline \multirow[t]{2}{*}{$\begin{array}{l}\text { Explanatory } \\
\text { Variable }\end{array}$} & Free cash flow & $\mathrm{FCF}$ & $\begin{array}{c}\text { net cash flow generated by } \\
\text { operating activities - } \\
\text { depreciation\& amortization - } \\
\text { expected investment (fitting value } \\
\text { of model } 1 \text { ) }\end{array}$ \\
\hline & Dividend payout ratio & DPR & $\begin{array}{l}\text { Dividend per share/Earnings per } \\
\text { share }\end{array}$ \\
\hline \multirow{7}{*}{ Control variable } & Growth & Growth & Tobin Q (B) value \\
\hline & Financial leverage & leverage & Asset-liability ratio \\
\hline & monetary fund & Cash & $\begin{array}{c}\text { (cash balance + traded financial } \\
\text { assets)/total assets. }\end{array}$ \\
\hline & Enterprise age & Age & $\begin{array}{c}\text { The difference between the } \\
\text { company's listing year and the } \\
\text { corresponding year. }\end{array}$ \\
\hline & The enterprise scale & Size & Ln(total assets) \\
\hline & Returns & Returns & ROA \\
\hline & Majority shareholder & Comr & $\begin{array}{c}\text { (other receivables - other } \\
\text { payable)/total assets. }\end{array}$ \\
\hline
\end{tabular}




\subsection{Regression coefficient text}

In order to obtain the fitting value of the expected investment model and the over-investment level of the enterprise, the results of model (1) are analyzed and obtained. The regression results of model (1) are as follows:

Table 2. Varabile Regression Coefficient

\begin{tabular}{cccccc}
\hline $\mathbf{p}$ & Coef. & $\mathbf{t}$ & $\mathbf{P}>\mathbf{t}$ & $\mathbf{R}^{2}$ & 0.0678 \\
\hline Growth & -0.001 & -1.43 & 0.015 & $\mathbf{F}$ & 79.25 \\
\hline Leverage & -0.009 & -3.02 & 0.003 & $\mathbf{P}>\mathbf{F}$ & 0.000 \\
\hline Cash & 0.109 & 9.17 & 0.000 & & \\
\hline Age & -0.002 & -6.59 & 0.000 & & \\
\hline Size & 0.008 & 4.97 & 0.000 & & \\
\hline Returns & 0.033 & 4.58 & 0.000 & & \\
\hline$I_{N E W_{\mathrm{i}, t-1}}$ & 0.234 & 11.77 & 0.000 & & \\
\hline Cons & -0.153 & -4.17 & 0.000 & & \\
\hline
\end{tabular}

The above model R squared is 0.0678 , and the fitting degree of the model is not high, but it can also explain the explanatory ability of the variable to the interpreted variable, and the linear model can be established. It can be concluded from the $\mathrm{F}$ test that the model of eliminating heteroscedasticity is more capable of explaining the explanatory variable. Analyze the numerical values of each variable in the regression model, and the following conclusions can be obtained:

The growth opportunity of listed companies, Tobin Q, is negatively related to the company's expected investment for the year, This may be due to better investment opportunities for companies with stronger growth and more excellent investment opportunities., which can be partly curb over-investment. Company debt levels and the expected investment level is significantly negative relationship, which are consistent with previous research results, which showes that when corporate debt increases, free cash flow is reduced, which will curb over-investment. There is a significant negative correlation between the listed years of the company and the expected investment of the company. The shorter the company's market time, the less good investment opportunities will be.And the company will have stronger tendency to over-investment. Company's last year's investment with this year's expected investment very significant positive correlation between, the author believes that this may be caused by the enterprise investment preferences, also may be due to the sustainability of investment project. Certain positive correlation between accounting earnings and the expected investment relations, this may be because, the higher accounting earnings, retained earnings will increase, managers will consider using retained earnings to expand the investment. The larger the investment opportunity, the greater the expected investment.

Using the residual error of the model, we can get the efficiency of investment level, When the residual is positive, it shows that the enterprise has over-investment and the residual term is negative, which indicates that there is a shortage of investment in the enterprise. Among the 7634 samples of the model, there were 3402 samples of excessive investment behavior, indicating that the sample of over investment accounts for about $45 \%$ of the total sample. This indicates that the over-investment behavior of our listed companies is more common. In the following study, this paper used 3402 samples of over-investment behavior to test the relationship between over-investment and free cash flow, and the relationship between dividend policy and over-investment.

To test the possible positive correlation between free cash flow and over-investment, we built model (2). 
Over_inv ${ }_{i, t}=\beta_{0}+\beta_{1}$ FCF $_{i, t}+\beta_{2}$ Growth $_{i, t}+\beta_{3}$ Leverage $_{i, t}+\beta_{4}$ Age $_{i, t}+\beta_{5}$ Size $_{i, t}+\beta_{6}$ Comr $_{i, t}(2)$

Table 3. Hypothesis 1 Regression Coefficient

\begin{tabular}{cccccc}
\hline $\mathbf{p}$ & Coef. & $\mathbf{t}$ & $\mathbf{P}>\mathbf{t}$ & $\mathbf{R}^{2}$ & 0.020 \\
\hline FCF & $3.43 E-13$ & 2.54 & 0.059 & $\mathbf{F}$ & 11.63 \\
\hline Growth & -0.003 & -4.49 & 0.000 & $\mathbf{P}>\mathbf{F}$ & 0.000 \\
\hline Leverage & -0.010 & -2.8 & 0.005 & & \\
\hline Age & -0.000 & -2.26 & 0.024 & & \\
\hline Size & 0.002 & 1.4 & 0.163 & & \\
\hline Comr & 0.002 & 0.19 & 0.851 & & \\
\hline Cons & 0.098 & 3.8 & 0.000 & & \\
\hline
\end{tabular}

The results show a significant positive correlation between free cash flow and over-investment: the more free cash flow the company has, the more serious the over-investment will be. In line with the previous conclusions, tobin Q, asset-liability ratio and listed years are negatively correlated with over-investment. However, the relationship between the large shareholders and the over-investment is not significant, and it is not clear that the anticipated large shareholders will increase the over-investment.

To test hypothesis 2, whether cash dividend can reduce cash flow and curb excessive investment, the following model (3) is set:

Over_inv ${ }_{i, t}=\beta_{0}+\beta_{1}$ GLZFL $_{i, t}+\beta_{2}$ Growth $_{i, t}+\beta_{3}$ Leverage $_{i, t}+\beta_{4}$ FCF $_{i, t}+\beta_{5}$ Age $_{i, t}+\beta_{6}$ Size $_{i, t}+\beta_{7}$ Comr (3)

Table 4. Hypothesis 2 Regression Coefficient

\begin{tabular}{cccccc}
\hline $\mathbf{p}$ & Coef. & $\mathbf{t}$ & $\mathbf{P}>\mathbf{t}$ & $\mathbf{R}^{2}$ & 0.020 \\
\hline GLZFL & -0.001 & -0.69 & 0.491 & $\mathbf{F}$ & 10.04 \\
\hline FCF & $3.45 \mathrm{E}-14$ & 2.55 & 0.059 & $\mathbf{P}>\mathbf{F}$ & 0.000 \\
\hline Growth & -0.003 & -4.47 & 0.000 & & \\
\hline Leverage & -0.010 & -2.83 & 0.005 & & \\
\hline Age & -0.000 & -2.33 & 0.02 & & \\
\hline Size & 0.002 & 1.38 & 0.167 & & \\
\hline Comr & 0.002 & 0.21 & 0.835 & & \\
\hline cons & 0.098 & 3.81 & 0.000 & &
\end{tabular}

Regression results show that dividend payout ratio is negatively correlated with over-investment, but not significant. The distribution of cash dividends will reduce the degree of over-investment to a certain extent. The result also shows that at the same time, due to the effect of cash dividend, free cash flow and over-investment coefficient decreased significantly, which means cash dividend by reducing the free cash flow of the enterprise, and suppressing the excessive investment, it also proves the hypothesis 2 .

\subsection{Extensibility test}

Through the summary and study of relevant literature, I found that different scholars have different opinions for the measure of company's growth .Richardson, used the $\mathrm{V} / \mathrm{P}$ this metric to measure growth,while some domestic scholars used main business growth rate to measure. Considering the 
availability of data, this paper selects the main business growth rate to replace tobin Q to test the robustness test of model (1), and the regression results are shown :

Table5. Extensibility Coefficient

\begin{tabular}{cccccc}
\hline $\mathbf{p}$ & Coef. & $\mathbf{t}$ & $\mathbf{P}>\mathbf{t}$ & $\mathbf{R}^{2}$ & 0.0685 \\
\hline MBGT & $-9.46 E-07$ & -1.81 & 0.042 & $\mathbf{F}$ & 79.97 \\
\hline Leverage & -0.009 & -3 & 0.003 & $\mathbf{P}>\mathbf{F}$ & 0.000 \\
\hline Cash & 0.111 & 9.39 & 0.000 & & \\
\hline Age & -0.002 & -6.61 & 0.000 & & \\
\hline Size & 0.008 & 5.05 & 0.000 & & \\
\hline Returns & 0.035 & 4.88 & 0.000 & & \\
\hline$I_{N E W_{i, t-1}}$ & 0.233 & 11.72 & 0.000 & & \\
\hline Cons & -0.138 & -4.16 & 0.000 & & \\
\hline
\end{tabular}

From this table, we can see just like Tobin Q, the main business growth rate is also negatively correlated with the company's expected investment this year. The relationship between other variables and this year's expected investment is consistent with model (1). This indicates that whether tobin Q or main business growth rate is the substitution variable of the growth of the company, it has no effect on the result. Therefore, the expected investment efficiency model is reasonable and the results are stable.

\section{Conclusions}

Based on the financial data of Listed Companies in four years from 2010 to 2013, this paper makes an empirical study on the relationship between free cash flow and over investment behavior, as well as the constraint function of cash dividends on over investment. The results of empirical research show that the behavior of over-investment generally exists in China's listed companies and free cash flow there is significant positive correlation with over-investment, companies with a positive free cash flow is more likely to produce excessive investment, cash dividend has constraint function of excessive investment, but not dramatically. Specifically, there are three points:

First, the phenomenon of over-investment is widespread in listed companies. This paper adopts the research methods of Richardson, the enterprise's actual investment expenditure into the expected optimal investment spending and excessive investment in the two part of the expenditure, then by constructing the best expected investment model, finds that about $45 \%$ of the sample enterprises have the so-called overinvestment behavior.

Second, the free cash flow of listed companies is positively correlated with over-investment, and free cash flow is more prone to excessive investment. Through regression analysis of the free cash flow and over-investment, verify if managers have can free free cash flow, in under the condition of information asymmetry and interests are not consistent, they have an incentive to use free cash flow for over- investment to the pursuit of self-interest maximization, the more free cash flow and managers' control, the greater the chance of over- investment.

Third, the cash dividends of listed companies have no significant constraint on excessive investment. Through the regression analysis of cash dividend and over-investment, although the coefficient is negative, the result is not significant, and there is no expected result of dividend agent theory. According to the theory of dividend agency, higher cash dividend payout ratio can directly reduce the free cash flow of managers' control and restrain its excessive investment behavior. On the one hand, it may be because China's capital market is still immature, the regulatory mechanism is not 
perfect, and the regulatory role of cash dividend policy is still not obvious. On the other hand, it is possible that the sample time is short and there is a certain chance.

\section{References}

[1] Richardson, S, Over-Investment of Free Cash Flow,Review of Accounting Studies,vol.11, pp. 159-189, 2006.

[2] Liu Changguo, Corporate governance mechanism, free cash flow and over-investment behavior of listed companies,Economic science, vol.04, pp. 50-58, 2006.

[3] Yang huajun, hu yiming, Excessive investment in institutional environment and free cash flow,Management world, vol.09, pp. 99-106, 2007.

[4] Kalgay, A, Signaling, Information Content and the Reluctiance to Cut Dividends,Financial and Quantitative Analysis.vol.15, pp. 855-869, 1982.

[5] Jensen, M., W, Meckling,Theory of the Firm;Managerial Behavior,Agency Cost and Owership Structure,Journal of Financial Economics,vol.02, pp. 305-360, 1976.

[6] Jensen, M.Agency Costs of Free Cash Flow, Corporate Finance ang Takeovers,American Economic Review,vol.76, pp. 323-329, 1986.

[7] Jinfan , Research on the relationship between the corporate free cash flow and cash dividend policy,Chinese Accounting Education Society branch ,vol.10,2012.

[8] Shaw min, Cash dividend, internal cash flow and investment efficiency, Financial research, vol.10, pp. 117-134, 2010.

[9] Easterbroo, F, Two Agency-cost Explanations of Dividends, American Ecnomics Review,vol.04, pp. 650-659, 1984.

[10]Liu yinguo, jiao jian, zhang Chen, Dividend policy, free cash flow and excessive investment -- a study on corporate governance mechanism,Nankai management review,vol.18, pp.139-150, 2015. 